\title{
O CONSUMO DE CRÉDITO E SEUS PREJUÍZOS E OS BENEFÍCIOS NA SOCIEDADE: UM ESTUDO INTERPRETATIVISTA NA PERSPECTIVA DE IDOSOS COMO CONSUMIDORES
}

\author{
CONSUMER CREDIT AND ITS HARMS AND BENEFITS FOR SOCIETY: AN INTERPRETATIVE STUDY \\ FROM THE PERSPECTIVE OF THE ELDERLY AS CONSUMERS
}

EL CONSUMO DE CRÉDITO Y SUS PERJUICIOS Y BENEFICIOS EN LA SOCIEDAD: UN ESTUDIO INTERPRETATIVISTA EN LA PERSPECTIVA DE ANCIANOS COMO CONSUMIDORES

GUSTAVO TOMAZ DE ALMEIDA

Doutorando

Universidade do Estado de Minas Gerais - Brasil gustavo.almeida@uemg.br

ORCID: https://orcid.org/0000-0001-6321-168X

FERNANDA CAROLINE CHAGAS FERRÃO

Graduando

Centro Universitário de Belo Horizonte - Brasil

fernandachagas87@gmail.com

ORCID: https://orcid.org/0000-0003-4548-6940

JONATHAN AVELINO DA SILVA

Graduando

Centro Universitário de Belo Horizonte - Brasil

jonathanavelino31@yahoo.com

ORCID: https://orcid.org/0000-0002-0398-1612

BRUNO MEDEIROS ÁSSIMOS

Doutorando

Universidade Federal de Viçosa - Brasil

bruno.assimos@gmail.com

ORCID: https://orcid.org/0000-0003-1206-6376

Submetido em: 22/07/2018

Aprovado em: 03/10/2018

Doi: alcance.v25n3(Set/Dez).p381-401

\section{RESUMO}

0 consumo de crédito é um tema que tem interessado pesquisadores internacionais, embora haja muito espaço para discutir sobre suas relações no contexto nacional e sob o olhar do marketing e da sociedade. Nesse sentido, esse artigo objetiva compreender o consumo de crédito na terceira idade, apontando, entre outros, para os benefícios e/ou os prejuízos dessa relação. Metodologicamente, optou-se por um trabalho qualitativo - entrevistas individuais em profundidade com 12 idosos (73 horas de vídeo e 1.396 páginas de transcrição). Os dados foram interpretados via Análise de Conteúdo, formando três categorias: independência financeira e de vida, idosos e suas relações com os serviços financeiros e divergências nas narrativas dos participantes - 0 que aponta para grupos de idosos de acordo com a forma como eles consomem o crédito. Como resultados e considerações finais, e diferente de boa parte dos trabalhos anteriores, o que se nota é que o crédito assume uma dimensão simbólica 
particular nessa fase de vida, ao mesmo tempo em que se questionam as práticas de algumas organizações que levam o idoso a consumir o crédito de maneira desmedida.

Palavras-chave: Idosos; Consumo de Crédito; Marketing e Sociedade.

\section{ABSTRACT}

Consumer credit is a topic that has interested international researchers, although there is still plenty of room for discussion about its relationships in the national context and from the perspective of Marketing and Society. This article aims to understand the consumer credit among the elderly, pointing, among other factors, the benefits and/or losses of this relationship. Methodologically, we chose a qualitative work - individual in-depth interviews with twelve elderly people (seventy-three hours of video and 1,396 pages of transcription). The data were interpreted through Content Analysis, forming three categories: financial and life independence, the elderly and their relations with financial services, and divergences in the narratives of the participants - which points to groups of elderly people according to how they consume credit. As results and contributions, and unlike most of the previous work, what is noticed is that credit assumes a particular symbolic dimension in this phase of life, while questioning the practices of some organizations that lead the elderly to consume the credit in an excessive way.

Key-words: Elderly; Credit Consumption; Marketing and Society.

\section{RESUMEN}

El consumo de crédito es un tema que ha interesado a investigadores internacionales, aunque hay mucho espacio para discutir sobre sus relaciones en el contexto nacional y bajo la mirada del Marketing y la Sociedad. En ese sentido, este artículo objetiva comprender el consumo de crédito en la tercera edad, apuntando, entre otros, a los beneficios y/o perjuicios de esa relación. Metodológicamente, se optó por un trabajo cualitativo - entrevistas individuales en profundidad con 12 ancianos (73 horas de vídeo y 1.396 páginas de transcripción). Los datos fueron interpretados vía Análisis de Contenido, formando tres categorías: independencia financiera y de vida, ancianos y sus relaciones con los servicios financieros, y, divergencias en las narrativas de los participantes - lo que apunta a grupos de ancianos de acuerdo con la forma en que consume el crédito. Como resultados y consideraciones finales, y diferente de buena parte de los trabajos anteriores, lo que se nota es que el crédito asume una dimensión simbólica particular en esa fase de vida, al mismo tiempo que se cuestionan las prácticas de algunas organizaciones que llevan al anciano a la edad consumir el crédito de manera desmedida.

Palabras clave: Ancianos; Consumo de Crédito; Marketing y Sociedad.

\section{INTRODUÇÃO}

Nos últimos anos, alguns pesquisadores de marketing têm alertado para um tema pouco estudado na área: o consumo de crédito (Bernthal, Crockett, \& Rose, 2005; Langley, 2014; Peñaloza \& Barnhart, 2011). A partir desse alerta, o tema tem recebido atenção de acadêmicos de diferentes países, embora pouca atenção seja dada às relações dinâmicas do consumidor final com o seu crédito (consumo financeiro pessoal). Em complemento, as pesquisas anteriores raramente consideram a voz do sujeito que consome o crédito, a dívida nem sempre é posicionada como um problema de interesse dos pesquisadores de marketing, além de haver pouca literatura que trata 0 assunto sob uma perspectiva mais interpretativista (Langley, 2014).

No Brasil, o assunto também despertou o interesse de alguns pesquisadores de marketing. Em conjunto, esses trabalhos apontam para as dimensões culturais do consumo de crédito (Brusky \& Fortuna, 2002) como forma de forçar um autocontrole financeiro (Castilhos \& Rossi, 2009), como significado de materialismo (Ponchio \& Aranha, 2009), de distinção social ou expressão de dádiva (Mattoso \& Rocha, 2009). Contudo, não há investigações que direcionem o olhar em um mesmo campo para as relações do crédito com o consumidor idoso, reconhecendo em um mesmo estudo a existência de benefícios e/ou prejuízos dessa relação. Adiante, também são raros os estudos que direcionem para as diferenças nas narrativas em relação ao uso do crédito para os grupos de idosos. As poucas pesquisas existentes são internacionais, raramente são da área de marketing e apontam frequentemente para generalizações. Isso é, ao ler essas investigações em conjunto, é mais comum a 
percepção de um idoso que perde com o avanço da idade a sua capacidade individual de gerir o crédito pessoal, dependendo dos seus familiares, mesmo que sem uma procuração ou autorização formal (Littwin, 2012). As raras pesquisas de marketing sobre o tema apontam como o idoso posiciona sua identidade via crédito, embora acreditem que tal identidade fica limitada pelas interações interpessoais com familiares e amigos (Barnhart \& Peñaloza, 2013).

Essas e outras questões acenam para o gap teórico que essa pesquisa busca compreender melhor e que levou a pesquisar a seguinte questão: Como os idosos se relacionam com o consumo de crédito, apontando para benefícios e/ou prejuízos dessa relação? Consequentemente, o objetivo do trabalho é compreender como os idosos se relacionam com o consumo de crédito, apontando para benefícios e/ou prejuízos dessa relação. Para tanto, foram desenvolvidas entrevistas semiestruturadas com 12 idosos, face a face, com idade média de 70 anos e renda média familiar de $\mathrm{R} \$ 1.900,00$ por mês. Além disso, fez-se uso de anotações em diário de campo para enriquecer o corpus empírico. A análise qualitativa foi organizada em três categorias: (1) Independência financeira: na qual se observa o quanto a vida financeira estável aponta não só para uma liberdade financeira, mas também para uma liberdade de vida na fase idosa; (2) Idoso no contexto do crédito: na qual se assinala como os participantes da pesquisa se posicionam diante das diversas modalidades de crédito; (3) Diferenças entre os idosos: na qual se reflete o quanto os idosos são diferentes entre si quando o assunto é o consumo de crédito.

Avançando para as justificativas, é importante reconhecer que, via consumo, os idosos discursivamente afirmam, rejeitam ou negociam sua identidade nesta fase de vida (Barnhart \& Peñaloza, 2013), destacando que a agência do idoso em assuntos financeiros não se resume à racionalização e à vitimização perante a estrutura financeira, sendo influenciada também por aspectos sociais, históricos e culturais (Dalmoro \& Vitorazzi, 2016). Em relação ao consumo de crédito, por si só, é digno do tipo de atenção crítica que ainda precisa receber dos acadêmicos de marketing (Langley, 2014). Para o autor, existe um considerável potencial analítico para a academia investigar as relações pós-compra do consumo de crédito. Nesse sentido, embora as obrigações de dívida possam ser de ordem diferente daquelas da fidelidade à marca, do serviço pós-venda ou das garantias de produtos, por exemplo, estas obrigações são cada vez mais deslocadas dos domínios jurídico e regulamentar para o domínio do mercado (Langley, 2014). Nessa esfera, a posição dominante de alguns trabalhos acadêmicos de que existe um consumo de crédito como algo neutro, inevitável e mutuamente benéfico pode ocultar os prejuízos dessa relação. Isso porque essa visão normaliza uma realidade na qual a sociedade já não pode se dar ao luxo de viver sem o crédito caro, contribuindo para as exclusões e as desigualdades que os críticos chamam a atenção para novos trabalhos revelarem, já que têm influência dos desequilíbrios imediatos de poder (Soederberg, 2015). Finalmente, em relação à pessoa idosa no Brasil, "percebe-se uma negligência quanto ao estudo do consumo dessa faixa etária" e uma "lacuna no conhecimento no campo da pesquisa do consumidor", havendo pouca compreensão que esses consumidores estão "inseridos em um sistema de valores [...] em uma perspectiva simbólica e socialmente construída" (Pinto \& Pereira, 2014, pp. 152-153).

Este estudo pretende contribuir para a abordagem de pesquisa do marketing intitulada Transformative Consumer Research - TCR, visto que tanto os pressupostos desta pesquisa quanto da TCR se preocupam com o bem-estar relacionado a potencialidades, necessidades e consequências do consumo, crendo que as ações de marketing beneficiam ou prejudicam a noção de emancipação do consumidor (como felicidade e/ou satisfação percebida) e o bem-estar ambiental, econômico e social. Assim, espera-se que os resultados deste estudo possam ajudar os acadêmicos aderentes à TCR na procura por alternativas que ajudem socialmente os idosos consumidores de crédito, contribuindo também para o incremento teórico ao campo (Davis, Ozanne e Hill, 2016).

Em termos de estrutura, o texto está organizado da seguinte forma: na fundamentação teórica, o leitor compreenderá, primeiramente, o quanto o consumo de crédito é um tema pouco estudado por acadêmicos de marketing. Na sequência, será possivel entender como o consumo de crédito é também um instrumento político de poder - 0 que, por vezes, reforça as vulnerabilidades dos consumidores. Na parte final da fundamentação teórica, o leitor notará as características dos idosos como consumidores, bem como o conluio histórico de silêncio por parte dos acadêmicos de marketing em relação a essa pessoa. Adiante, na metodologia, há ênfase para a Análise de Conteúdo Categorial das informações verbais e não verbais. A análise de dados foi erguida a partir das três categorias já descritas nesta seção. $O$ artigo é encerrado com as considerações finais, destacando resultados e implicações diante do fato de a pesquisa encontrar o idoso assumindo diferentes perfis em relação ao consumo de crédito. 


\section{FUNDAMENTAÇÃO TEÓRICA}

\subsection{O Consumo de Crédito}

Os idosos possuem afinidades estreitas com o consumo de crédito, já que, nas muitas ocasiões que podem surgir na vida do consumidor, a pessoa permanece costurada em mercado de consumo com base no crédito (Maurer, 2014). Além disso, o crédito pode ser compreendido como uma mercadoria fabricada, comercializada e vendida (L'Estoile, 2014). Por isso, adota-se neste estudo a perspectiva de não tratar o tema apenas como uma moeda de troca, mas sim como o próprio bem de consumo (Maurer, 2014), que contribui para moldar a economia e a sociedade (Graeber, 2011). Maurer, Nelms e Swartz (2013) compactuam com a visão do crédito como uma mercadoria vendável, já que sua posse e descarte são componentes chave que geram um sentimento de liberdade individual no consumidor. Esse lado mais benéfico é a perspectiva mais comum nas pesquisas sobre o tema, apontando que o crédito tem lugar no estabelecimento de identidade e autoestima do consumidor (Neill, 2014). Apesar desses avanços, alguns trabalhos ainda caracterizam os idosos como aqueles que sempre procuram o serviço de aconselhamento ao crédito e que possuem boa aposentadoria (Xiao, Sorhaindo, \& Garman, 2006) e que optam racionalmente por consumir por meio do cartão de crédito (Pulina, 2010).

Reconhecem-se, porém, evoluções em periódicos como o Journal of Consumer Research - JCR, surtindo dez trabalhos que avançam ao compreender o lugar do consumo ao crédito na cultura e nas identidades individuais, derivando sentidos culturais de independência - integração social, indulgência, autodisciplina, segurança, restrição da liberdade (Peñaloza \& Barnhart, 2011), distinção de estilos de vida dentre as pessoas com maior capital cultural em relação as demais, o crédito como portador de uma capacidade paradoxal de liberdade ou aprisionamento panóptico (Bernthal et al., 2005) e impulsionando a autoestima (Garvey, Germann, \& Bolton, 2015). Ao utilizar de aspectos culturais em suas análises, esses trabalhos estão, geralmente, atrelados às experiências de consumo de crédito (ou falta dele) em momentos importantes da vida das pessoas, como a educação, a preparação para o trabalho, a compra ou a construção de um imóvel, o nascimento de um filho ou a aposentadoria (Peñaloza \& Barnhart, 2011). Em outros periódicos, o crédito aparece como cultura material (Maurer, Nelms, \& Swartz, 2013), expressão de dádiva (Brusky \& Fortuna, 2002) e bem social (Pereira \& Strehlau, 2012). $O$ crédito surge ainda para ajudar a produção e o governo de subjetividades coletivas e individuais (Lazzarato, 2012).

Os artigos anteriores também apontam o papel das instituições financeiras para promover o bem-estar dos consumidores, enfatizando, na maioria deles, somente o papel benéfico dessas organizações em relação ao consumidor. Por exemplo, Cohen (2007) parece destacar a 'ordem e o progresso' quando as instituições financeiras lançam programas educacionais para atacar os efeitos do consumo de crédito de forma exorbitante. Para reduzir esses problemas, o autor aposta no consumo consciente, o que cortaria os custos sociais do governo. Isso seria atingido por investimentos em educação, regulamentação de mercado e proteção do consumidor. Nessa concepção, a pessoa assume um papel mais passivo, de um tomador de informações instrumentais (o mundo é exterior a ela) para posterior conscientização.

As investigações acadêmicas anteriores também indicam que a obtenção do crédito vai além do ambiente organização-consumidor, tendo relações com a família ou as redes sociais próximas de amigos. Nesse sentido, apontam que os significados culturais do consumo têm relação com a dádiva, por exemplo, o empréstimo do próprio nome para um amigo obter crédito e 'maior acesso' ao mercado (Brusky \& Fortuna, 2002), algo simbólico e comum no Brasil (Alves, et al., 2013). Esse tipo de prática indica generosidade entre os pobres de redes sociais próximas diante uma emergência familiar (Pereira \& Strehlau, 2012). Neste caso, a dádiva pode possuir expressões de solidariedade e generosidade que "geram efeitos associados ao reforço vincular" (Vizeu, 2009, p. 418), estabelecendo pontes que permitem cultivar relacionamentos sociais, mesmo diante dos riscos, das incertezas e dos sacrifícios, mensurados por meios não objetivos (Mauss, 2003)

Contudo, Graff, Wann e Naylor (2002), embora com uma visão somente prejudicial sobre o consumo como epidemia, afirmam que, via crédito, as pessoas perdem a noção de que estão trabalhando com dinheiro de verdade. Afirmando que, diferente do que foi exposto anteriormente, o crédito carrega aspectos que prejudicam 0 bem-estar do consumidor. Esse cenário pode prejudicar o consumidor, por exemplo, ao emprestar o seu nome para um familiar ou amigo obter crédito financeiro mediante força ou engano - dívida coercitiva (Littwin, 2012) ou, ainda, os problemas decorrentes do fato de o idoso ser a faixa etária mais superendividada no Brasil, em virtude, principalmente, do empréstimo consignado (Baues, 2008). Além disso, as famílias brasileiras estão cada vez mais endividadas pelo fácil acesso às modalidades de crédito (cheque especial, crédito pessoal, cartão de crédito, crédito consignado e crédito direto ao consumidor) (Bortoluzzi, Boligon, Hollveg, \& Medeiros, 2015). 
Parece que a revisão de literatura exposta aborda um tema comum ao marketing, mas a maioria dos exemplos mencionados vêm do Direito (Littwin, 2012), da Psicologia (Baues, 2008), das Finanças (Bortoluzzi, Boligon, Hollveg, \& Medeiros, 2015) e do Serviço Social (Alves \& Wilson, 2008). Por isso, embora se reconheça que o tema consumo de crédito está presente em larga escala na literatura do marketing, em sua maioria, eles foram construídos sob a lente das estratégias de estímulo ao crédito adotadas pelo mercado financeiro (Nepomuceno \& Laroche, 2012). Em menor quantidade, observam-se alguns trabalhos que abordam os prejuízos do crédito na sociedade, envolvendo preocupações com o consumo de crédito e os consumidores vulneráveis (Bernthal, Crockett, \& Rose, Credit Cards as Lifestyle Facilitators, 2005; Peñaloza \& Barnhart, 2011). Por exemplo, no contexto brasileiro, alguns pesquisadores de marketing apontam o crédito como uma poupança invertida, em que se guarda o dinheiro para pagar o cartão de crédito ao final do mês. Surge também como autocontrole da sociedade, quando o consumidor se endivida para forçá-lo a controlar seu orçamento. Ou como declaração de materialismo e distinção, buscando demarcar uma posição social, separando o pobre dos pobres-pobres mais pobres ainda (Brusky \& Fortuna, 2002).

Finalmente, quando o enfoque é o endividamento, alguns estudos ressaltam as complexidades na esfera cultural. Nesse sentido, há investigações sobre o crédito como um bem social, percebendo 0 endividamento de forma menos negativa se for benéfico, como o crédito para ser reconhecido como um bom pai (Pereira \& Strehlau, 2012). Ou, ainda, o endividamento como algo desejável para usufruir níveis de consumo superiores ao rendimento disponível, ou importante em situações extraordinárias e emergenciais (Santos, Costa \& Teles, 2013).

Essas discussões, embora apontem para várias questões, ajudam a produzir o seguinte conhecimento sobre o fenômeno em estudo: 0 crédito tem relações muito próximas com o consumo de crédito, embora sejam raras as pesquisas de marketing que debatam 0 assunto. Dentre as pesquisas publicadas, é mais comum a perspectiva apenas benéfica do crédito, percebendo as instituições financeiras como "amiga" dos idosos. Numa perspectiva bem menos presente, há poucos estudos que visualizem só o lado negativo do crédito. Diferente do que se deparou na revisão, pressupõe-se que o consumo de crédito pode assumir as duas dimensões e que as instituições financeiras também podem assumir um papel de "vilão". Além disso, a revisão aponta que o crédito tem relações com as fases de vida, como aposentadoria, construção da moradia e ensino. Também se nota que a família influencia o consumo de crédito do idoso. Essas questões são importantes, pois são pontos percebidos nas narrativas dos idosos.

\subsection{Os impactos do consumo de crédito na sociedade}

Essa parte da revisão tem como objetivo reforçar o quanto as dimensões do crédito possuem relações íntimas com o meio no qual o idoso está inserido, por exemplo, a família. Além disso, uma questão muito recorrente no campo foi o quanto há um incentivo do consumo de crédito por parte das instituições financeiras. Nesse caso em específico, esse trecho da revisão objetiva embasar historicamente que essa perspectiva é antiga, isso é, que o crédito também é um produto para aumentar o lucro das instituições financeiras, com particularidades no Brasil, desde o Plano Real, passando pela crise no mercado subprime, bem como na recente liberação do FGTS. Essa revisão teórica objetiva que o leitor também entenda que o crédito é um instrumento de controle governamental o que "explica" algumas posturas de naturalizar certos prejuízos como se fossem inerentes ao mercado de crédito. Por este motivo, a revisão também resgata o empréstimo consignado e, em especial, a sua falta de regulamentação, percebendo o crédito como um produto vendável e não apenas um meio para obter algo. Essa falta de regulamentação reforça vulnerabilidades aos idosos, que é a discussão final dessa seção.

0 consumo de crédito tem impacto na sociedade em abordagens mais estruturais e também no comportamento desse consumidor, como em Fisher (2012) e Ho (2009). Trabalhos que se preocupam com tais impactos são reunidos em três frentes principais: 1) há desequilíbrio de poder entre o consumo e mercado, por exemplo, em Villareal (2014); 2), os números não medem fenômenos complexos relacionados ao consumo de crédito, como em Shore e Wright (2015); 3), os sistemas de análise de crédito institucionalizaram-se em categorias sociais (como etnia, classe, gênero ou raça) e fortalecem privilégios e desvantagens entre grupos, como descrito por Schuster (2014). No Brasil, o antropólogo L'Estoile (2014), ao desenvolver etnografias no contexto brasileiro, ajuda a desvendar aspectos culturais do consumo de crédito, apontando, por exemplo, que um dever para se tornar um homem, chefe de familia, é sustentar individualmente a casa (colocar dinheiro em casa) no contexto das familias nordestinas. Ainda sobre o consumo de crédito no contexto nacional, o setor bancário brasileiro sofreu forte reestruturação com a implantação do Plano Real. Antes disso, "as altas taxas de inflação garantiam aos bancos receitas de intermediação financeira que surgiam devido aos depósitos à vista e às aplicações de curto

Revista Alcance - Eletrônica - vol. 25 - n. 3 - Set./Dez. 2018 
prazo não sofrerem correção monetária integral" (Martins, Bortoluzzo, \& Lazzarini, 2014, p. 90). Com a inflação controlada, a expansão do crédito bancário foi a fonte alternativa para gerar novas receitas, aumentando $80,9 \%$ entre junho de 1994 e março de 1995, o que Martins, Bortoluzzo e Lazzarini (2014) chamam de competição bancária em todo o Brasil, equivalente a 'quem vende' mais crédito?

O consumo de crédito amplia suas dimensões em 2008 , quando a crise financeira originada no mercado de crédito imobiliário norte-americano promoveu um corte mundial da oferta de crédito, receando inadimplência. Mas o governo brasileiro adotou uma postura anticíclica e fortaleceu os bancos públicos, que apresentaram forte crescimento da oferta de crédito, nesse período, e se tornaram agentes importantes para injetar dinheiro na economia em todo o Brasil a reagir já nos primeiros meses de 2009. Essa prática de utilizar o crédito como um instrumento de controle prevalece nos dias atuais. llustrando um caso afim, a partir do discurso do presidente da República, em 14/02/2017, durante a cerimônia de anúncio da liberação do saque de contas inativas do FGTS: "todos se reuniram e discutimos como injetar valores na economia brasileira. E sobre injetar valores na economia brasileira, [...] não só injetaria recursos na economia, como traria de alguma maneira uma certa tranquilidade social" (Temer, 2017, grifamos). No discurso oficial, fica clara a justificativa de estimular a sociedade para consumir o crédito, visando injetar o dinheiro na economia. Ou seja, a norma que lhe é imposta pelo Estado é a capacidade e a vontade de desempenhar o papel de consumidor (Bauman, Vida para consumo, 2008) para financiar o cofre das organizações financeiras brasileiras, que obtiveram lucro superior a 57,7 bilhões de reais em 2016, quando somados os resultados só da Caixa, Itaú, Bradesco, Brasil e Santander (FEEP, 2017). Em complemento, as instituições mencionadas estão no topo das organizações que mais pagam dividendos ao redor do mundo (FEEP, 2017). Para Baudrillard (2006), esse cenário se desdobra em uma postura inconsciente por parte do consumidor, como se nota a seguir:

O sistema do crédito coloca aqui um máximo à irresponsabilidade do homem frente a si mesmo: aquele que compra aliena aquele que paga, trata-se do mesmo homem, mas o sistema, pelo seu desnível no tempo, faz com que não se tenha consciência disso. (Baudrillard, 2006, p. 171).

Umas das modalidades de crédito que são rentáveis a essas grandes instituições ao redor de todo 0 Brasil é o empréstimo consignado, visto que 0 desconto direto na remuneração do trabalhador garante inadimplência praticamente igual a zero. Trata-se de uma modalidade recorrente de acesso ao crédito, fornecido por instituições financeiras e sociedades de arrendamento mercantil, em que o desconto da prestação ocorre diretamente na folha de pagamento ou benefício previdenciário (Baues, 2008). O Banco Central orienta fazer 0 crédito consignado apenas para atender suas necessidades. Mas o consumidor de crédito não busca atender apenas necessidades restritamente relacionadas à carência de bens e serviços (Gonzalez, 2015). Isso porque, se pensar em Hegel (1998), a necessidade é mais típica dos animais, que a experimentam como ausência de alguma coisa, seja o alimento quando estão com fome ou o parceiro quando tem impulsos sexuais. Diferente disto, os seres humanos experimentam o desejo de reconhecimento: serem amados, logo, ser artefato de desejo do outro, o que tem relação próxima com o consumo.

Outro impacto do consumo de crédito na sociedade é decorrente de peças publicitárias enganosas face ao desconhecimento. Contudo, mesmo o consumidor sendo mais conhecedor do crédito, as estratégias discursivas e semióticas de captura via persuasão, fartamente utilizadas nas campanhas, são mais problemáticas. Por isso, a pesquisa reforça que "o crédito não é mero meio, mas um produto" e a saída seria "atenção e regulação especial" "assemelhada a produtos como medicamentos e bebidas alcóolicas" (Hennigen, Schmidt, \& Souza, 2015, p. 43).

Em outro trabalho, Hennigen e Carvalho (2014) investigam que as condições de fornecimento de crédito (as regras) são ocultadas nas peças. Os autores questionam: "seria tal apagamento justamente uma condição de possibilidade para a sua fácil 'vendabilidade' junto aos consumidores? Se elas estivessem bem explicitadas, não provocariam maior reflexão e reticências?" (Hennigen \& Carvalho, 2014, p. 241). Em outra pesquisa, os autores percebem um paradoxo, pois os folhetos convidam a consumir o crédito para responder qualquer circunstância, incitando seu uso frenético; contudo as cartilhas trazem orientações severas para quem se endivida e não paga, transferindo a responsabilidade integralmente para o consumidor (Hennigen \& Bonazza, 2014).

Além disso, se destaca o constrangimento dos consumidores (super) endividados para falar sobre o tema. Esses participantes destacavam seu endividamento diante do fácil acesso ao crédito: crédito estudantil, plano de saúde, cartão de crédito, redução de impostos, etc. (Hennigen \& Gehlen, 2012). Por isso, existe pouca produção 
sobre os "conhecimentos e intervenções que abram espaços para as pessoas refletirem e, assim, transcenderem as condições que os engendram" (Hennigen \& Gehlen, 2012, p. 297). Em relação ao constrangimento, é algo esperado, já que até o ano de 2010, por exemplo, havia uma previsão vigente desde o ano de 1943 na Consolidação das Leis Trabalhistas, na qual o funcionário poderia ser demitido por justa causa por falta de pagamento de dívida, embora a prática de consulta de restrições de nome permaneça até hoje, justificada pela "natureza do cargo a ser ocupado" (Hennigen \& Gehlen, 2012, p. 296).

Noutro trabalho, Costa e Hennigen (2012, p. 393) entrevistam funcionários do Programa Estadual de Proteção e Defesa do Consumidor - PROCON e alguns dos seus materiais fornecidos para o consumidor. Nesse aspecto, é observado que nenhum dos registros do órgão apontam uma única reclamação sobre publicidade abusiva na venda de crédito e questionam "Será que a publicidade no Brasil é tão "correta e ética assim?". Nesse caso, a ideia é transcender "a noção de vulnerabilidade [e] as possibilidades do trabalho em prol da defesa do consumidor buscando [também] seu empoderamento" (Costa \& Hennigen, 2010, p. 393). Em outra pesquisa, entrevistando 24 consumidores, Hennigen (2012, p. 1) aponta que o consumo de crédito é muito impactado em termos de benefícios e prejuízos quando ocorrem "acidentes de vida (desemprego, doença, separação, etc.)". Dentre os prejuízos, a autora menciona as seguintes questões:

\begin{abstract}
Verifiquei uma dupla marcação sobre o consumidor: por um lado, apesar de ser decorrente de uma rede de fatores, é ao indivíduo que se atribui a responsabilização pela situação - o que é assimilado por ele e traz a vivência de culpa, vergonha e toda ordem de mal-estar e dificuldades; por outro, encontra-se o estigma moral, pois quem não consegue honrar dívidas fica com o nome sujo, que não se restringe à esfera comercial - é a pessoa mesma que cai em descrédito (Hennigen, 2012, p. 1).
\end{abstract}

Diante de tantas descobertas, Hennigen $(2010$, p. 1176) "assinala a urgência de se estudar e problematizar" o consumo de crédito e a incorporação "de segmentos sociais potencialmente mais vulneráveis como os idosos/aposentados".

\title{
2.30 'ser' idoso
}

Não é novidade para o marketing perceber o idoso como consumidor. Quando se avalia a literatura, observa-se a existência de pesquisas em 1981 no Journal of Consumer Research, apontando que não há relação entre o volume de crédito disponível para o consumidor idoso e o nível de consumo de eletricidade de sua residência (Warriner, 1981). Mas só nos anos mais recentes que reforçam perspectivas para além dos aspectos utilitários, envolvendo também os aspectos culturais e simbólicos dos idosos como consumidores. Em uma das pesquisas, Barnhart e Peñaloza (2013) demonstram o quanto o consumo ajuda a negociar e a conhecer a identidade na velhice e se expressa como um fenômeno de grupo, afetando o comportamento de consumo de outros membros da família que residem no mesmo ambiente.

Nas pesquisas brasileiras em marketing, uma boa parte ainda estuda os seus comportamentos, dada "a importância do segmento dos idosos no mercado de consumo", contudo sem pesar o empoderamento desse público (Paço, 2015, p. 84). Em situações como esta, a população idosa é vista mais em virtude do "crescimento cada vez maior de um segmento do mercado", sendo que a "identificação de hábitos de consumo [...] pode revelar informações mercadológicas valiosas sobre suas preferências e facilitar o desempenho das indústrias" (Mendonça, Relvas, \& Correa, 2010, p. 529). Avançando, então, para as publicações internacionais, também se encontra um volume pequeno de trabalhos de marketing sobre idosos, sendo que a maioria das pesquisas encontradas desejam mais um aumento de participação de mercado. Por isso, carecem novos estudos sobre a diversidade entre 0 público idoso, dado que Sorianno e Dias (2010) descrevem que esses consumidores possuem particularidades entre si. O significado da velhice e possíveis incapacidades dos idosos é uma construção sociocultural, com forte influência da religião, fatores de classe social e valores, e bem menos em aspectos biológicos. Por isso, os autores sugerem que novas pesquisas devem se preocupar com demandas específicas do contexto de acordo com a diversidade cultural dos idosos.

Outra pesquisa destaca os desafios e as oportunidades na pesquisa sobre consumidores em situação de risco - por exemplo, os idosos, que podem ser prejudicados por práticas de marketing para tirar o máximo partido das oportunidades de mercado (Pechmann, et al., 2011). Finalmente, outro trabalho reforça a noção que os idosos possuem diferenças de estilo de vida que podem ser segmentados, dentre outros, com base no crédito

Revista Alcance - Eletrônica - vol. 25 - n. 3 - Set./Dez. 2018 
(Grece, 1987). Pensando no impacto (em termos de benefícios e prejuízos) na fase idosa, existe um atraso quando analisada a perspectiva histórica. Isso porque as reflexões sobre o consumidor idoso é a expressão analítica mais tardia, se pensar sobre a ausência política desse público nos movimentos sociais nas crises da década de 1960, como o movimento estudantil, o hippie, o feminista e o negro (Britto da Motta, 2009). No Brasil, os idosos começam a aparecer muito timidamente no contexto da retomada democrática dos anos de 1980; contudo se firma apenas nos anos de 1990, em virtude do crescimento demográfico dessa população, do maior envolvimento com os movimentos, como a fundação de clubes e universidades específicos para a chamada terceira idade. Mas é também nesse momento que a representação negativa desse público impõe prejuízos aos idosos decorrentes, por exemplo, da necessidade da reforma dos direitos e dos deveres previdenciários (Britto da Motta, 2009).

Esse conluio histórico do silêncio também está presente na academia. Desse modo, embora a produção sobre os idosos tenha destaque desde 1950, em decorrência da transição demográfica nos Estados Unidos e países europeus, somente a partir de 1980 que a terceira idade vem recebendo maior atenção dos pesquisadores brasileiros, apesar de ainda incipiente (Castro, Guilam, Sousa, \& Marcondes, 2013). Em relação à tentativa de reduzir os impactos prejudiciais, é só mais recentemente, em 2006, que a Organização Mundial da Saúde - OMS instituiu o dia 15 de junho como o Dia Mundial da Conscientização da Violência a Pessoa Idosa (Ministério da Saúde, 2017). No contexto do crédito, alguns idosos são alvos de prejuízos, porque controlam boa parte da riqueza mundial, ou nem sempre percebem o preço dos seus ativos; são suscetíveis ao controle do outro em caso de deficiências; têm padrões previsíveis de quando terão dinheiro em mãos; nem sempre denunciam os agressores por adoecimento ou constrangimento; podem não ter testemunhas convincentes; podem estar mortos antes da intervenção legal em casos de idade mais avançada; alguns não procuram apoio jurídico e uma parcela conhece pouco os assuntos financeiros, leis, direitos e avanços tecnológicos que perpassam o crédito (NCPEA, 2017). Os prejuízos podem ser maiores em casos de isolamento, solidão, perdas recentes de parentes, desemprego na família, deficiência física ou mental (NCPEA, 2017), podendo atingir homens e mulheres de diferentes classes sociais (Irigary, Esteves, Pacheco, Grassi-Oliveira, \& Argimon, 2016).

No marketing, os artigos publicados em periódicos acadêmicos sobre os prejuízos do crédito focam mais os esquemas fraudulentos de telemarketing. Em um dos artigos, os autores relatam os resultados de um programa contra essas fraudes nos Estados Unidos. A iniciativa conscientizou milhões de idosos por uma parceria entre investigadores policiais, empresas de serviços postais, organizações provedoras de internet, trabalhadores voluntariados e por intermédio dos meios de comunicação - jornal, rádio e televisão. Logo no início, o programa National Telemarketing Victim Call Center conseguiu contatos com 20 mil potenciais vítimas de telemarketing abusivo durante um ano (Aziz, Bolick, Kleinman, \& Shadel, 2008). Em outro trabalho, os pesquisadores posicionam os crimes de telemarketing como um dos efeitos da solidão. As vítimas isoladas socialmente tinham entre 60 e 70 anos (Alves \& Wilson, 2008). Noutro estudo, os pesquisadores avaliam estatisticamente a tendência do idoso em ser vítima desse crime. Embora o trabalho não consiga verificar um perfil coeso, uma variável afetou a vitimização, indicando que os entrevistados eram mais propensos ao engano se acreditassem na verdade dita pelo vendedor ao telefone (Reiboldt \& Vogel, 2003). Finalmente, num quarto e último trabalho, os pesquisadores sugerem 0 programa-modelo do Estado de Oregon, que possui treinamento multimídia e vai às residências orientar como ignorar chamadas telefônicas e e-mails suspeitos "na cena do crime" (Kaye \& Darling, 2000, p. 99).

Essas questões ajudam a embasar teoricamente esse estudo, apontando que, embora os acadêmicos de marketing tenham trabalhos sobre os idosos há alguns anos, só mais recentemente que se visualiza o consumo para além dos seus aspectos utilitários. Isso é importante, visto que essa pesquisa se adere a essas poucas investigações, percebendo o crédito para além do seu valor utilitário. Além disso, quando se revisa a produção nacional, nota-se que os idosos são percebidos mais frequentemente como um segmento de mercado. Por isso, carecem estudos que percebam os impactos do consumo na vida do idoso, sejam eles benéficos ou prejudiciais - o que levou esse estudo a perceber tanto os benefícios quanto os prejuízos existentes nessa relação. Para essa atividade, quando se recorre à produção internacional, embora existam poucos trabalhos que discorram sobre os idosos, nota-se que os autores apontam que há espaço para novos estudos que percebam os idosos como consumidores. Esse tipo de estudo ajuda a reduzir o conluio histórico de silêncio sobre as vulnerabilidades dos idosos. Essa constatação teórica levou o estudo a propor uma categoria que discute as divergências de narrativas sobre o controle financeiro dos idosos, isso é, perceber as diferenças existentes entre os participantes - e não a coesão. Finalmente, a revisão aponta que os prejuízos do consumo de crédito são mais presentes em estudos que refletem sobre as fraudes de telemarketing, embora quase nenhum avanço sobre essa discussão seja vista no Brasil. Nesse sentido, o estudo pretende ir além dos prejuízos relacionados ao telemarketing, visualizando outros prejuízos na relação entre o idoso e o consumo de crédito. 


\section{METODOLOGIA}

O estudo se insere no campo das pesquisas qualitativas, interpretativas e exploratórias (Cooper \& Schindler, 2016). Adotou-se o método qualitativo, pois embora se reconheçam os avanços dos métodos quantitativos, é questionável se a cultura de medição pode ser adequada para compreender os benefícios e os prejuízos do crédito nas suas diversas expressões, especialmente pelo fato de o tema ainda ser pouco estudado na perspectiva antipositivista - o que justifica a adoção da pesquisa exploratória e interpretativista. Além disso, o interpretativismo foi selecionado em virtude das crenças ontológicas dos pesquisadores, crendo que o mundo social é essencialmente relativista e só pode ser compreendido a partir do ponto de vista dos indivíduos que estão diretamente envolvidos nas atividades estudadas. 0 mundo só existe a partir do quadro de referência de quem participa da ação, local em que o homem é, de certo modo, autônomo e tem livre arbítrio, isso é, o mundo é uma construção social. $O$ interpretativismo tem como principal preocupação a compreensão da maneira pela qual 0 indivíduo cria, modifica e interpreta o mundo em que se encontra. A realidade é única e particular para o indivíduo (Burrell \& Morgan, 1979), coerente com a pesquisa que enfatiza a natureza relativista do consumo de crédito.

Adiante, vale esclarecer que a pesquisa foi realizada no Estado de Minas Gerais, com idosos residentes em Belo Horizonte e região metropolitana - com idade média de 70 anos e renda mensal familiar de $R \$ 1.900,00$. Para essa atividade, foram convidados a participar da pesquisa quatro idosos; no entanto, no avanço da coleta dos dados, foi observado que esse número seria insuficiente para retratar o objetivo da pesquisa. Realizaram-se 12 entrevistas em virtude da saturação dos dados, que iniciou a partir da $8^{a}$ entrevista e foi confirmada quando se chegou-se à $12^{\mathrm{a}}$. Diante disto, foram entrevistadas mais 8 pessoas, quando se chegou a uma narrativa mais robusta. 0 critério de seleção dos participantes foi acessibilidade e disponibilidade (Cooper \& Schindler, 2016), avaliadas com a leitura e assinatura do Termo de Consentimento Livre e Esclarecido - TCLE. A coleta de dados durou 58 dias seguidos. Os encontros ocorreram na residência dos idosos e locais próximos - como praças e ruas. Embora não seja usual a realização de entrevistas em profundidade em ruas ou praças, esses locais eram quase em frente à casa dos participantes, o que permitiu um deslocamento de forma rápida e contínua. Além disso, eram locais relativamente silenciosos, não comprometendo a qualidade das gravações. Finalmente, esse lugar foi um pedido do participante, que se sentiria mais confortável, uma vez que poderia falar algo que não diria próximo a outros familiares que moram ou estavam de visita - visto que, por vezes, o nome de um parente era recorrente e poderia surgir uma narrativa de conflito familiar decorrente do consumo de crédito. Essa coleta ocorreu por intermédio de uma entrevista semiestruturada (Cooper \& Schindler, 2016) a partir de um roteiro prévio elaborado com base na revisão de literatura, envolvendo questões como: Conte-me como controla seu crédito. Como você chegou à situação de endividamento [se aplicado]? Como utiliza os serviços bancários para obter o crédito?

As entrevistas foram gravadas em vídeo, possibilitando o resgate verbal e não verbal, e ocorreram face a face e individualmente. Logo após os encontros, cada entrevistador fez o registro de informações em um diário de campo - 37 páginas. As primeiras 4 entrevistas duraram em média 8 horas e 30 minutos cada, e as demais cerca de 4 horas - uma vez que nesse segundo momento se conheciam as categorias de análise a partir das entrevistas iniciais, indo a campo com perguntas mais direcionadas. As primeiras entrevistas ocorreram em cerca de 5 a 7 encontros, ao passo que a segunda ocorreu entre 3 a 4 encontros - para não cansar o participante. Ao todo, obtiveram-se 73 horas e 8 minutos de vídeo, que foram transcritos na íntegra - resultando mais 1.396 páginas de texto. Nenhuma entrevista foi descartada da análise. Os participantes tinham idade entre 60 e 86 anos, e se dividiram em 4 homens e 8 mulheres, com vida financeira aparentemente estável. Além disso, optou-se por identificá-los pela letra "I", de idoso, seguido dos números de 1 a 12 (I1, I2 ... I12), para manter o sigilo da sua identificação (Tabela 1).

\section{Tabela 1}

Perfil dos entrevistados

\begin{tabular}{l|c|l|c}
\hline ENTREVISTADO & IDADE & ENTREVISTADO & IDADE \\
\hline 11 & 60 & 17 & 69 \\
\hline 12 & 60 & 18 & 73 \\
\hline 13 & 60 & 19 & 78 \\
\hline 14 & 62 & 110 & 79 \\
\hline 15 & 64 & 111 & 81 \\
\hline 16 & 68 & 112 & 86 \\
\hline
\end{tabular}

Fonte: Dados da pesquisa (2018). 
Logo após a transcrição, os dados foram interpretados por meio da Análise de Conteúdo Categorial, que se propõe a descrever e a interpretar alguns dos sentidos que a leitura de um conjunto de textos pode suscitar (Bardin, 2015). O método apoia-se em um processo de construção da compreensão do texto, a partir de uma sequência recursiva composta por três etapas: a desconstrução do corpus, a unitarização e a categorização. Nessa etapa, também foram organizadas as análises dos dados não verbais das entrevistas, resgatados por intermédio da gravação das entrevistas e/ou das anotações em diário de campo. Esse tipo de análise foi feito e é percebido na apresentação dos dados, resgatando o conteúdo de um gesto, de um sentimento e/ou emoção, ou uma ação, por exemplo, descrevendo o tom de exaltação ou euforia presente na narrativa, a ação do participante de ir pegar uma passagem área para mostrar para o entrevistador ou os risos presentes em uma narrativa.

Após essa etapa de unitarização, passou-se, entre abril e maio de 2018, à organização dos significados semelhantes, chamada de etapa de categorização, na qual são reunidos os enxertos semelhantes, gerando diversos níveis de categorias de análise. Nessa fase, fez-se uso do software Atlas TI@, para selecionar narrativas que produziam sentidos. Este processo gerou metatextos analíticos que compuseram os textos interpretativos da análise de conteúdo (Bardin, 2015). Após construída a categorização, triangularam-se os resultados a partir da análise dos diários, das transcrições e dos vídeos, havendo ainda a confrontação por pares entre os pesquisadores que estiveram na entrevista. Não havendo divergências nessa etapa, as principais conclusões foram sintetizadas e serão apresentadas na próxima seção.

\section{SÍNTESE DOS PRINCIPAIS RESULTADOS}

A análise foi realizada a partir das narrativas dos entrevistados e sua interação com o entrevistador. Essa etapa foi essencial para orientar os entrevistadores a alcançarem os sentidos e as suas variações, nem sempre visíveis. Durante a leitura detalhada e cuidadosa das entrevistas, foram encontrados pontos recorrentes em quase todos os encontros e que contribuíram na construção das categorias relacionadas ao consumo de crédito. Dentro desses, foram criadas as seguintes categorias de análise: independência financeira e de vida dos idosos; o idoso e os serviços financeiros e as divergências de narrativas dos idosos.

\subsection{Independência financeira e de vida dos idosos}

De início, vale esclarecer que nesta pesquisa consideram-se idosos indivíduos com 60 anos ou mais, segundo a definição do estatuto do idoso (BRASIL, 2003). Alguns estudos qualitativos revelam que pessoas dessa idade em diante valorizam o bom relacionamento com a família, os amigos, a saúde, a participação em organizações sociais e o trabalho. Esses estudos também indicam 0 quanto a situação financeira estável e controlada é fundamental para que o idoso promulgue sua independência não só financeira, como também na vida (Barnhart \& Peñaloza, 2013). Essa postura pode ser significada com a liberdade de fazer o que se quer, a segurança de satisfazer suas necessidades e desejos, oriunda de uma renda proveniente de formas como 0 salário, a aposentadoria, os investimentos e a poupança (Bernthal, Crockett, \& Rose, 2005). Este cenário é vivenciado pelos idosos participantes da pesquisa, que, ao serem questionados sobre a independência financeira, apresentam no decorrer de suas narrativas a autoafirmação da independência de vida, como se observa:

"Acordo cinco e meia da manhã e vou pra minhas faxinas. Com dinheiro das faxinas compro minhas roupas, compro também pros netos, ajudo a pagar as contas, ajudo meu filho a 'paga' a faculdade e ainda vou com [...] (fala o nome do marido) para [...] (fala o nome da cidade natal do seu marido)." (I3)

"Com meu consignado [...] vô pro CEASA, compro minhas verdura, compro ração pras galinha, saio com minhas amigas pro forró e com que sobra vou diverti lá pras Caldas Novas com minha filha." (19)

"[O principal crédito vem de um] Bucado de casa de aluguel. Construí isso tudo com empréstimo [...]. Com dinheiro que sobra vou lá pra Paraíba viajar, toma banho de praia." (112)

"Eu não preciso deles [falando dos filhos] e nem eles precisam de mim [...]. Pra mim meu momento tá muito bom [...], agora dia seis tô indo pra Rondônia de avião ainda (em tom de exaltação). 'Vo' dia seis, pago no cartão de crédito uma passagem de ida e volta - que é promoção. [...] 'Mile' e cento e noventa real que e promoção. 'Vo' pra Porto Velho. De lá pego a Van pra ir pra cidade. 'Vo' pro casamento da sobrinha, matar 
'vaga' gorda. Aqui a passagem de avião (novamente em tom de euforia). Tá aqui dentro (se levantou, pegou a passagem e a mostrou)." (17)

Ao analisar as entrevistas em conjunto, percebe-se que esses idosos têm uma preocupação com sua emancipação de vida e financeira, visto que eles fazem questão de ostentar a autossuficiência em suas finanças, mesmo que seja necessário recorrer ao consumo de crédito (como o cartão ou um empréstimo), o que também é documentado em pesquisas anteriores (Brusky \& Fortuna, 2002). Com base nas narrativas, é possível identificar que a maioria das pessoas entrevistadas veem sua atual situação de maneira favorável, estando no comando de suas decisões sem o auxílio ou as opiniões de terceiros. Consumir o crédito não é um problema para elas - pelo contrário, é motivo de louvor para uma parcela. Esta postura independente parece indicar relação com a forma engajada que alguns idosos percebem o presente:

\begin{abstract}
"Eu não preciso deles [falando novamente dos filhos] e nem eles precisam de mim [...] Por enquanto, não preciso da família em nada [...] eu não passo momento difícil nenhum. Preciso [de crédito], uso o cartão, o consignado, peço um vizinho, um amigo." (17)

"Quando tenho vontade de comer algo, eu compro, já tive vontade de comer e não podia comprar [...]. Hoje, com o consignado, realizei o sonho de fazer a festa de 15 anos da [...] [menciona o nome da filha mais nova], reformei minha casa e consegui fazer minha 'prastica' depois da redução." (I1)
\end{abstract}

Ao investigar os hábitos e os comportamentos desses consumidores idosos, depara-se com um perfil esperançoso e otimista que estes entrevistados dão ao consumo de crédito. Como evidenciado no trecho a seguir, eles parecem confortáveis e satisfeitos com a própria situação de vida e financeira: "Hoje meu dinheiro me dá um conforto que nunca tive" (I2).

"Não me preocupo, não preciso levanta às 05 , hoje só ir lá no banco pega meu dinheirinho [referindo ao crédito pré-aprovado] [...]. Agora [referindo-se à fase idosa] consigo viver." (110)

"Se eu não fizer besteira de gastar com outras coisas, minha aposentadoria e o cartão [de crédito] é o suficiente [...]. Vai tudo pra despesa de casa. Pago tudo sozinha. Junto pra viajar fim de ano. Ajudo a minha mãe no interior, mando $R \$ 200,00, R \$ 300,00$ todo mês e ajudo minha filha mais velha [32 anos]. Pago a prestação do apartamento da minha filha mais velha às vezes." (I1)

"Tenho um caderno que faço as anotações. Consigo controlar dinheiro sim e pagar as dívidas. Se for algo pra que preciso, faço isso melhor que o meu marido." (I5)

"Eu, pelo menos, eu sou assim: eu compro, passo o cartão e eu fico feliz porque eu sei que vou ter pra mim paga lá. Eu num tenho dúvida não, eu tenho certeza que eu vou ter [dinheiro] pra pagar lá, então eu fico feliz [...]. Eu não desperdiço dinheiro não, é igual aqui, aqui no bairro aqui eu compro fiado [...] todo mundo confia. Fico feliz em poder fazer isso." (18)

"Ter o nome limpo na minha idade é bom demais. Compro o que quero fiado; uso o meu dinheiro do jeito que quero. Não devo nada pra ninguém. Não peço favor, nem pra família." (14)

"Adoro ir pro forró com minhas amigas. Gasto eles [os consignados] tudo com isso se eu quiser. E viajo também, com minha filha. Mas do forró não abro mão de jeito nenhum [de ter crédito para esse lazer]. [...] É meu divertimento. Já trabalhei demais nessa vida, agora é só aproveitar, 'num' devo ninguém mesmo." (111)

Nota-se que, mesmo devendo e assumindo consignados constantes, o último relato carrega o sentimento de que não possui dívida com ninguém, talvez se referindo a uma dívida moral. Em complemento, muitos dos artigos anteriores abordam o público da terceira idade, como aquele indivíduo cansado e ressaltam o declínio nesta fase, como descrito na revisão de literatura. No entanto, o campo aponta para idosos com disposição e força para viver, sugerindo persistência e determinação, já que "hoje tenho o que queria ter, saio com mais amigos, passo o cartão e não me preocupo" (15). 
Em síntese, essa parte da análise aponta para os benefícios do consumo de crédito ao ilustrar não só a autoafirmação da independência financeira dos idosos entrevistados, mas também como eles utilizam essa liberdade financeira para declarar sua liberdade de vida. Percebe-se que isso ocorre quando os idosos avaliam a própria vida financeira na terceira idade, atrelando-a à tranquilidade, à disposição, à felicidade, à saúde, à independência e às realizações, especialmente quando recorrem ao consumo de crédito. Na totalidade das narrativas, nenhum entrevistado aponta problemas relacionados à saúde, ao cansaço físico e emocional. Diferente dessa perspectiva, consideram-se satisfeitos quanto à a vida e ao seu crédito - mesmo que o dinheiro seja pouco, é o suficiente para serem felizes, na perspectiva dos entrevistados. Isso sugere que a terceira idade é vivenciada por alguns como uma nova etapa a ser desfrutada com planos, envolvendo viagens para o lazer, reforma ou compra da casa própria e aproveitar a vida com familiares e amigos - 0 que alguns dos participantes não puderam em outro momento da vida e agora podem, com a facilidade de acesso ao consumo de crédito, segundo anotações em diário de campo.

Contudo, em termos de prejuízos, parece haver nas entrelinhas um desconhecimento por parte do idoso, que encara o consumo de crédito como se fosse um aumento de renda. Nesse sentido, situações como 0 endividamento ou o fato de essas pessoas não poderem se dar "ao luxo" de viver sem o crédito, pois a aposentadoria não é suficiente por si só, parecem ser banalizadas por essas pessoas. Em nenhuma das entrevistas o participante relatou que alguém o alertou sobre os prejuízos decorrentes do atraso no pagamento do cartão de crédito ou que há desembolso de juros na tomada de um consignado. Segundo anotações em diário de campo, os bancos são narrados como amigos dos idosos - coerente com a revisão de literatura. Essas instituições fazem um telemarketing contínuo ("o senhor tal, você tem um crédito disponível"), mas nenhum bancário esclareceu aos participantes sobre os prejuízos, já que esse "crédito disponível" tem juros e retira uma parcela do valor da aposentadoria. Quando questionam os bancários sobre o depósito a menor, os entrevistados relatam que ouvem: "quem deposita é o INSS, a gente só repassa". Assim, ainda em termos de prejuízo, nota-se que falta um consumo consciente do consumo de crédito, no sentido de que os participantes consomem o crédito sem um domínio consciente dos benefícios e dos prejuízos do acesso a esse mercado.

\subsection{Idosos e suas relações com os serviços financeiros}

Essa parte do artigo está organizada em três momentos, de acordo com a modalidade de consumo de crédito. No primeiro, o foco principal será discutir sobre os empréstimos; no segundo, os cartões de crédito, encerrando ao abordar sobre o financiamento. Nesse sentido, o empréstimo é um meio rápido e fácil para se obter recursos financeiros com a promessa de grande facilidade no pagamento e existem várias modalidades como consignado, cheque especial, cheque pessoal, com penhor, entre outros. Podem ser realizados no mercado formal por meio de bancos e financeiras e/ou obtidos no mercado informal, por meio de amigos ou agiotas. Um dos pontos negativos desta modalidade de consumo de crédito, contudo, é a taxa de juros, seguido de longos prazos de pagamento, em algumas situações (Annavarapu, 2016).

No campo, a motivação para a contratação de um empréstimo pode variar muito: desde uma situação extrema em que não há outra saída a não ser fazê-lo, ou até mesmo para começar o próprio negócio nessa nova fase etária na vida (Agnew \& Cameron-Agnew, 2015; Castilhos \& Rossi, 2009). Com base na descrição de suas experiências, é possível constatar que a maioria dos entrevistados fizeram uso de empréstimos ao longo de sua vida. Raros são os casos que, mesmo com frequentes ofertas, seduções e assédios por parte dos serviços financeiros, eles conseguiram resistir à tentação e relatarem que existe outra forma de superar os obstáculos. Para essas poucas exceções, "as pessoas possuem uma dívida, se realizarem o empréstimo, trocam por uma maior" (17). Nos demais casos, em coerência com a revisão de literatura, a maioria dos entrevistados aderiram ao empréstimo no mercado formal ou informal (Bernthal, Crockett, \& Rose, 2005), com propósitos diversos, como "reformar a casa própria" (I2), conceder dinheiro "a uma suposta namorada que acabou de conhecer" (Diário de campo do dia 04 de abril, relativo ao l12), amparar um conhecido de sua igreja, o qual não faz parte de sua família, "mas está passando por momentos difíceis" (I6).

Mesmo assim, embora eles reconheçam os benefícios do consumo de crédito (felicidade e tranquilidade), como discutido na seção anterior, parece haver alguns perigos nessa relação. Um dos participantes relata que algumas instituições insistem por telefone em oferecer supostos serviços de educação financeira pautados também em ofertas de crédito e serviços bancários (Diário de campo do dia 03 de março, relativo ao I6). Embora o entrevistado pareça não ver malícia nesse telemarketing, parece existir uma espécie de "venda casada" e bem maliciosa - pouco relatada nas produções acadêmicas (Alves \& Wilson, 2008). A sedução, contudo, não se 
restringe aos serviços financeiros formais, atingindo o mercado informal - que é uma situação ainda menos vista na revisão de literatura. Certa entrevistada, por exemplo, afirma: "nunca fiz empréstimos com bancos e evito a relação" (18), mas admite "ter adquirido com terceiros" (Diário de campo do dia 05 de abril, relativo ao 18).

Por intermédio da análise descrita, a principal conclusão que se pode chegar é que, em sua maioria, parece não haver a necessidade eminente da contratação do empréstimo, e que mesmo sendo contrários a esse consumo de crédito, alguns acabam adotando o seu uso, especialmente, em virtude da sedução ou da necessidade de retribuir o que o outro fez - como se fosse uma expressão de dádiva relativa à etapa de retribuir por alguém que the ajudou ou pode the ser útil no futuro, ou ainda que você tenha proximidade (Baues, 2008; Mauss, 2003).

O segundo ponto da discussão relativo ao cartão de crédito parece ser um facilitador no momento em que se vai comprar algum bem (Bernthal, Crockett, \& Rose, 2005). O cartão é como se fosse um 'empréstimo' que o usuário pode parcelar o valor da compra, além de efetuar o pagamento da fatura em até 40 dias - por exemplo. 0 grande problema é quando ocorre a utilização imprópria e inconsequente. Nessa situação, se o usuário não conseguir pagar o valor total da fatura, geralmente, são oferecidas duas modalidades de pagamento: rotativo $\mathrm{e}$ parcelado. A nova complicação é que os juros são muito altos e isso acaba virando uma bola de neve (Bauman, 2010). Outro problema são as cobranças indevidas que 'de vez em quando' aparecem na fatura. Vale lembrar também que geralmente os fornecedores dos cartões de crédito são bancos, mas também podem ser emitidos por outras instituições.

Trazendo para a realidade do campo em análise, os entrevistados têm narrativas variadas. Alguns dizem que não simpatizam com "cartões de crédito" e "parcelamento de compras" (I9; I2) e "nunca utilizaram, pois não confiam" (Diário de campo do dia 17 de abril, relativo ao 17). Entretanto, um deles, mesmo narrando isso, afirmou que "se precisar em situações de urgência, faço o uso com muito cuidado" (I2). Além disso, alguns entrevistados comentam o aprendizado ou 'medo' da terceira idade - relativo ao uso do cartão de crédito que desdobrou em problemas no seu passado - quando ainda não eram idosos. Essa situação gera o desuso do cartão de crédito na fase de vida atual, para evitar que esses inconvenientes se repitam. Logo, por problemas passados, "hoje evito o cartão de crédito" (I3). Mas o lado oposto também é percebido. E o intrigante é que 0 uso do cartão acabou ocasionando um endividamento, mas o crédito nem foi direcionado à pessoa idosa. Isso acontece, por exemplo, com quem pegou o dinheiro "para ajudar uma mulher desconhecida" (112) ou "para ajudar a família, sempre que necessário" (16).

Há também quem possui o cartão de crédito de lojas de varejo para não ter contato direto com os bancos - pelos traumas passados, mas assume que já fez diversas compras parceladas com esse cartão, visto que facilita a compra, uma vez que "é mais difícil juntar o dinheiro para comprar à vista, né" (I1). O que se vê nessa parte da análise, embora haja o lado propositivo da relação entre o idoso e os serviços bancários, é que ela também permeia algumas 'maldades', como a oferta desmedida de produtos e serviços financeiros (Barnhart \& Peñaloza, 2013), que não se limita aos serviços bancários (Dalmoro \& Vitorazzi, 2016). Pode-se reconhecer que existe também a facilidade de se obter bens e serviços no mercado, e de outro lado há o pântano de dívidas como resultado de um uso irresponsável e negligente - que pode ser ocasionado também pelo assédio constante dos fornecedores de crédito.

O terceiro e último ponto dessa categoria de análise é o financiamento. Ele é um consumo de crédito com garantia de bens, ou uma compra parcelada de um produto no qual se agregam juros ao montante inicial. Existem vários tipos de financiamento - vale lembrar, muitos com subsídio do governo. Esse tema foi o que obteve menos relatos de campo. Mas quando emergem na narrativa, essa modalidade parece não agradar os usuários que foram entrevistados. Na primeira descrição, o idoso participante tem um contato indireto com o financiamento, isso é, o crédito não foi realizado pelo idoso, mas por uma filha. Nessa situação, em momentos de dificuldade, "ajudo minha filha com o pagamento, usando meu próprio crédito" (11) disponível. Em outro relato, o financiamento foi realizado para se "adquirir um veículo" (I5). Percebe-se que o financiamento não é comum entre estes entrevistados, mas está presente em alguns relatos.

Apesar disso, e pensando em termos de prejuízos do consumo de crédito, vale novamente reforçar uma situação percebida em outro momento da análise - 0 fato de o idoso obter o crédito, mas não fazer uso próprio dele. A revisão de literatura acena que essa situação ocorre, por exemplo, em decorrência dos juros menores oferecidos a esse público idoso, especialmente pela possibilidade de desconto direto em sua aposentadoria (a consignação). $O$ que cabe refletir é que isso pode representar uma redução substancial de sua renda - afinal, a aposentadoria, por vezes, é a única fonte ou a fonte principal de renda de alguns idosos. Na outra ponta, estão as

Revista Alcance - Eletrônica - vol. 25 - n. 3 - Set./Dez. 2018 
organizações financeiras, cada vez mais saturadas de metas de trabalho para obter o salário variável - ou mais do que isso, manterem seu emprego. Para baterem seus indicadores, elas se transvestem em serviços alternativos (como a intrigante Educação Financeira fornecida de forma questionável por alguns bancos); e, na outra ponta, oferecem, também de maneira questionável, produtos e serviços financeiros, como se fosse uma venda casada. Vê-se essa situação recentemente debatida pela academia nacional em gestão (Dalmoro \& Vitorazzi, 2016).

Assim, embora haja benefícios simbólicos para o idoso em ajudar um familiar, as anotações em diário de campo levam a constatar prejuízos no consumo de crédito, quando os fornecedores de crédito veem o idoso como uma presa fácil para bater sua meta, seja pela sua baixa instrução, pela docilidade no trato, pela carência de atenção por parte dos seus familiares que ele acaba por 'acreditar' e depositar confiança no discurso decorado do seu gerente de contas, dentre outras situações que sugerem ao campo da gestão refletir criticamente sobre a relação do idoso com os serviços financeiros - uma prática reificada no mercado e naturalizada aos olhos da sociedade.

\subsection{Divergência de narrativas sobre o controle financeiro dos idosos}

Nessa terceira e última categoria de análise, pode-se notar que existem diferenças entre os idosos no trato com o seu crédito. Isso parece 'natural', mas não é o que se percebe na revisão de literatura, que geralmente se refere à pessoa idosa como se fosse apenas um 'coitado', que precisa do apoio de terceiros para se tornar sujeito. É como se, ao chegar a essa fase de vida, a área de gestão o tratasse academicamente como se tivesse morrido. Para discutir essas divergências das narrativas dos idosos, começa-se com a adoção ou não de serviços bancários por essas pessoas. Isso porque, com a inserção na terceira idade e consequente direito à aposentadoria, para alguns, reiteradamente os idosos são induzidos a continuarem ou se tornarem consumidores de serviços bancários para recebimento do seu benefício previdenciário (Dalmoro \& Vitorazzi, 2016). Desta forma, pode-se distinguir os entrevistados de duas formas: (a) participantes que são adeptas das contas bancárias a fim de manter controle financeiro; e (b) que passaram a usufruir deste serviço somente em virtude do recebimento do benefício. Esta distinção fica clara nos relatos, como: "Quando sobra algum [dinheiro] coloco no banco... Se ficar em casa, gasta né?" (15), que se relaciona ao primeiro grupo.

"Controlo o meu dinheiro quando vo lá, recebo o pagamento, pago as contas, compro mantimento, comprar o que precisa e o restante eu coloco no banco. Tentar guardar um dinheirinho!" (I8)

Opostamente, a maioria dos idosos entrevistados apresentam-se amplamente receosos quanto à utilização de quaisquer serviços bancários devido às informações sobre possíveis dolos, levando a outros hábitos, como juntar o dinheiro, mas fora do banco: "Gosto muito de banco não, que minha leitura [no sentido de entendimento, conhecimento] é fraca" (I1); "Guardo e junto debaixo do colchão" (19); "Eu empresto e depois cobro com juros" (I3). Contudo, o outro lado também é observado, isso é, que nem todos os entrevistados conseguem guardar dinheiro, mas vivem no limite: "Difícil juntar dinheiro, ainda mais para quem vive de aposentadoria... Meio complicado" (111); "Consigo controlar dinheiro sim se for algo para que preciso, melhor que o meu marido. Mas guardar, não." (I3); "Junta não chega a junta, mas falta num falta" (I5). Isso pode ser explicado, entre outros motivos, visto que as falhas começam logo no início da aposentadoria: o cidadão idoso nem sempre se planeja para a queda na renda e, com a idade avançada, ocorre o horizonte de gastos mais altos com médicos e remédios. Daí as contas vão chegando, a pensão não acompanha e vai batendo o desespero, segundo anotações em diário de campo.

Para além da divergência nas narrativas relativas ao uso de serviços bancários, é também divergente a opinião sobre o consumo ou não do crédito. Vale lembrar que a falta do controle financeiro pessoal é um dos agravantes para que os idosos consumirem cada vez mais o crédito que é disponibilizado a todo o momento (Dalmoro \& Vitorazzi, 2016). É possível observar que alguns entrevistados se mostram a favor, em situações que eles consideram oportunas: "Já fiz empréstimo para reformar a casa... se sobra eu invisto em casa" (I4); "Eu gosto de cartão de crédito, dá pra compra sem pagar na hora, o ruim é 'té' que pagar depois" (I11). Enquanto outros, avessos ao consumo de crédito, indagam sobre a possibilidade de agravantes financeiros: "O banco cobra muitos juros e eu não sou bobo (risos)" (I2); "Não quero saber de cartão nem a 'pau'... Tem que pagar, se não pagar se 'lasca' [risos]" (I10). 
Existem também os idosos que se diferenciam dos dois relatos mencionados - que ocupam os extremos de polos opostos (nunca pegarei versus pego com frequência). Nesse caso, embora ele tenha pegado no passado, os problemas que decorreram desse fato fazem com que certas pessoas evitem serviços bancários. Mas como comentado na categoria anterior, é mais comum o idoso entrevistado fazer o uso dos serviços bancários, como os empréstimos (pessoal e consignado), financiamentos e cartão de crédito. No campo fica nítido o quanto o idoso parece ser o principal alvo do consumo de crédito, já que os bancos perceberam que os idosos estão mais ativos e começaram a facilitar empréstimos. Mas muitos pegam mais dinheiro do que devem e acabam perdendo 0 controle (Bauman, Vida a crédito, 2010), e é aí que reside o perigo, como se nota:

"Eu já fiz alguma coisa mas não faço nunca mais esse trem de financeira e esse trem de cartão. $O$ banco se você dever ele $R \$ 500,00$ ele te cobra $R \$ 5.000,00$." (111)

Além disso, apesar de o consumo de crédito estar atrelado à possibilidade de atuar como forma de pagamento e influenciar o poder de compra, contribui para a elevação do endividamento, podendo comprometer a saúde financeira doméstica (Lazzarato, 2012) do idoso. Afinal, o serviço bancário de acesso ao crédito não significa aumento de renda, dado que a pessoa se compromete a restituir ao banco o principal com os respectivos juros. Em consonância, percebe-se que, mesmo sem ter cursado uma educação financeira instrumental, há participante que expressa conhecimentos sobre os riscos do consumo de crédito, descartando a possibilidade extrema de uso:

"Não mexo com cartão de crédito, não uso isso. Não compro em cartão, nada disso [...]. Eu num compro trem fiado, eu não compro no cartão, eu num compro em nada [...] eu vou comprar pra quê?" (11).

Todavia, e em sintonia com a noção de divergência nas narrativas dos idosos - que é a proposta dessa categoria de análise -, outros participantes da pesquisa manifestam adesão em casos de necessidade familiar atual ou num passado próximo: "Não gosto de mexer com cartão e nada de parcelamento, mas já fiz quando precisei reformar a casa" (I12). Em casos como estes, os entrevistados também consomem o crédito e preferem 'investir' nos seus familiares do que em serviços bancários ou nele próprio.

"Eu gosto de pegar crédito e gastar tudo com ela né [a neta], é muito melhor. Gasto com os estudos da minha neta. Até porque né... eu? Prefiro mesmo investi nos estudos dela, ela tem uma vida toda pela frente e eu já tô velha né, de idade [...]." (18)

Do mesmo modo, outro entrevistado não quer saber de consumir crédito, indo diretamente ao banco, pois prefere financiar as compras com o limite existente no cartão de crédito para o seu lazer e descanso (Diário de campo dia 15 de maio de 2018, relativo ao 17).

"Eu gosto de viajar muito, vo pelo menos 'trê' vezes ao ano. E é de avião! [...] Eu gosto de visitar os meus parentes, ir viajar, cada um mora num lugar, num cantinho diferente. [...] Eu pego 0 cartão de crédito, pago a passagem, mas não entro no banco de jeito nenhum. $\mathrm{A}$ passagem aqui, eu gosto mermo é de passear, não gosto de ficar em casa não." (17)

Essas e outras ilustrações no campo apontam reflexões interessantes para diferentes públicos. Em termos de prejuízos, vale destacar que, se por um lado as instituições financeiras estão cada vez mais buscando a aproximação com seus clientes, de outro lado alguns idosos estão buscando cada vez mais distância - em virtude de práticas questionáveis por parte de algumas organizações -, em momentos atuais ou anteriores da vida do idoso que causaram prejuízos. Já em termos de benefícios, independente do relacionamento com o banco, há aqueles que fazem questão de ter o crédito para aplicarem naquilo que consideram ser um bom investimento, algo rentável - como investir na educação de um familiar ou no seu próprio lazer. Essas situações particulares dos idosos refletem uma má Educação Financeira? Aparentemente, parece que não. Isso porque os participantes parecem consumir crédito para aproveitar a vida de uma forma mais saudável, com base em projetos que consideram prioritários na fase atual de vida - e que outrora não puderam realizar, por exemplo, pelo ritmo de trabalho. 


\section{CONSIDERAÇÕES FINAIS}

Por meio deste estudo foi possível refletir sobre algumas situações vivenciadas pelos idosos, em especial, mostrar as suas relações com o consumo de crédito, por exemplo, como eles lidam com a oferta ostensiva, de que maneira é investido o tempo com o recurso obtido, bem como demonstrar as relações entre o consumo de crédito e os estilos de vida na terceira idade, dentre outras situações. No decorrer da construção deste artigo, deparou-se com aspectos que instigam a tecer algumas considerações.

A revisão de literatura aponta que existe um estímulo ao consumo ao crédito, fomentando, por exemplo, um crescimento e desenvolvimento econômico. Por outro lado, esse estímulo pode carregar sentidos prejudiciais, devido ao endividamento e ao possível desdobramento no consumismo exagerado em decorrência do maior acesso ao crédito e, por consequência, bens e serviços. Igualmente, no campo, alguns idosos são atraídos pelas facilidades e simplicidades na hora de adquirir o crédito. Com isso, os idosos se tornam um alvo fácil para os bancos e as financeiras, o que aponta para uma relação perigosa e prejudicial. Mas existem participantes da pesquisa que conseguem extrair mais benefícios que prejuízos na sua relação com o consumo de crédito. Isso ocorre mesmo quando esses participantes fazem a gestão do crédito de modo mais simplista (por exemplo, anotando em cadernetas), pois não possuem um conhecimento para lidar com o avanço da tecnologia. Mesmo com controles menos robustos, a boa gestão do crédito leva não só para uma independência financeira, mas reflete a autoafirmação de vida saudável e feliz, dando uma sensação de qualidade e liberdade de vida, embora possa refletir uma felicidade paradoxal, pois o crédito também carrega uma espécie de aprisionamento panóptico.

$\mathrm{Na}$ segunda categoria de análise, observou-se como o idoso lida com os fornecedores de crédito, como bancos e demais instituições financeiras. Nesse caso, os participantes relatam a forma ostensiva de oferta de crédito, reforçando a ideia de que os idosos são alvos constantes de telemarketing, dado o menor risco de inadimplência, pois o pagamento de algumas modalidades é realizado direto no benefício previdenciário. Notase, ainda, que alguns entrevistados já tiveram problemas com seus agentes credores, levando a um receio sobre o crédito disponível no mercado.

$\mathrm{Na}$ última categoria de análise, pode-se verificar as diferenças nas narrativas sobre o consumo de crédito. Nota-se que alguns idosos tiveram problemas financeiros, seja com financiamentos ou com o gasto abusivo do cartão de crédito. Além disso, os créditos consignados viraram uma sobrevida na renda de alguns idosos. Contudo, o oposto também existe, dado que a pesquisa encontrou idosos avessos ao consumo de crédito. Podese notar que alguns já utilizaram algumas modalidades, mas outros salientam que só procuram os agentes credores em situações de grande necessidade, para não entrarem numa bola de neve de dívidas. Finalmente, vêse uma situação interessante: de um lado existem alguns fornecedores de crédito buscando uma aproximação maior com o público da terceira idade; do outro lado, estão alguns idosos buscando cada vez mais distância em relação aos agentes credores, muitas vezes, em consequência de práticas questionáveis por parte de algumas instituições financeiras.

Frente a essas constatações, vale lembrar que o objetivo desse artigo foi compreender como os idosos se relacionam com o consumo de crédito, apontando para benefícios e/ou prejuízos dessa relação. Nesse caso, o estudo constatou que o limite entre a existência de benefícios e prejuízos se relaciona, entre outros aspectos, com o passado da pessoa idosa (o aprendizado contínuo materializado na análise pelas experiências ao longo da vida) e o relacionamento do idoso com os seus familiares. Nesse caso, em alguns momentos, os prejuízos surgem quando os familiares percebem o idoso como um cartão de crédito ambulante, devido à facilidade e à simplicidade que o participante dessa idade encontra ao adquirir o crédito na praça. Já os benefícios apontam para o uso do crédito coerente com o aumento da expectativa de vida do idoso. Em outras palavras, notou-se que o velho de ontem, que ficava sentado esperando a morte (que geralmente vinha cedo), já não reflete a totalidade da população idosa. Hoje, os idosos entrevistados parecem querer viver a vida em sua plenitude. Nessa tarefa, 0 consumo do crédito o auxilia para gozar e ostentar os benefícios dessa vida, quando a renda mensal não é suficiente.

Também se nota, como resultados e implicações da pesquisa, um desconhecimento do consumidor do crédito sobre as condições desse serviço. Por vezes, há um equívoco nessa situação, como se 0 acesso ao empréstimo representasse um aumento de renda. Utilizando de artifícios do marketing (por exemplo, o telemarketing), essa situação é reforçada mediante o uso de termos por vendedores de crédito, como "o senhor tem um crédito disponível", representando um "canto de sereia" para alguns dos consumidores. Tal situação se exacerba com a ideia de interseccionalidade, na qual o problema se desdobra ou tem origem em outros domínios 
que 0 idoso nem sempre tem acesso. Por exemplo, a ausência de um ensino de qualidade e de educação financeira no passado do idoso pode aumentar o desconhecimento na leitura dos termos do contrato de obtenção de crédito. Em complemento, o idoso também encontra acesso "fácil" ao consumo de crédito no mercado informal. Isso foi percebido como presente no campo por intermédio do "empréstimo do nome" para alguém obter crédito, as compras a prazo entre partes que têm intimidade (fiado entre conhecidos), o empréstimo da aposentadoria a quem 0 idoso tem confiança e/ou vice-versa (empréstimo consignado para um familiar descontado na aposentadoria), dentre outras situações.

Em suma, encontra-se o idoso assumindo diferentes perfis em relação ao crédito. Assim, um idoso acaba pegando o crédito sem condições de arcar com o pagamento com sua renda atual (perfil endividado). Contudo, com 0 acesso ao crédito, ele acaba tendo acesso também aos bens e aos serviços que influenciam beneficamente sua autoestima (perfil produtor de identidade) e/ou tendo acesso a algo que the foi negado quando ele era jovem (o marginalizado). E, agora, com idade mais avançada, alguns dos idosos não vão abrir mão de terem uma boa vida. No processo de obtenção de crédito, esse mesmo consumidor acaba por cair em possíveis golpes cometidos (o coitadinho), por exemplo, por funcionários bancários, que chamam o idoso de "amigo" para fornecer-lhe cada vez mais crédito. Também foi observado que 0 uso do crédito tem significados para além da independência financeira, atingindo também a independência de vida do idoso. Desse modo, obter o crédito assume um sentido de felicidade, no sentido de o idoso dizer "eu tenho" e "eu posso" ajudar o meu filho. Esse cenário se diferencia da maioria das pesquisas anteriores, que destaca um idoso com declínio cognitivo e sem condições de cuidar de si e do outro.

Todavia, o estudo está envolto em inúmeras limitações. Uma delas está no fato do recorte geográfico, que pode estar influenciado por uma cultura de consumo específica. Outro ponto é que se entrevistaram em profundidade 12 idosos. Logo, os relatos podem refletir as perspectivas dessas pessoas e não dos idosos de um modo geral. Além disso, esse é um estudo exploratório. Logo, novas pesquisas podem aprofundar na discussão, compreendendo, por exemplo, o papel das instituições financeiras para fomentar benefícios e/ou prejuízos na relação idoso-crédito. Finalmente, o familiar também é um agente interessante para novos estudos, já que se observou o quanto o idoso toma o crédito para assumir desejos das pessoas que o rodeiam.

\section{REFERÊNCIAS}

Agnew, S., \& Cameron-Agnew, T. (2015). The influence of consumer socialisation in the home on gender differences in financial literacy. International Journal of Consumer Studies, 39(6), pp. 630-638. doi:10.1111/ijcs. 12179

Alves, G. L., Stucchi, B. O., Mahmoud, R., Nascimento, B., Sampaio, Y., \& Bacha, M. L. (2013). Baixa renda: endividamento e compreensão de notícias econômicas. Inovcom, 5(2), pp. 38-51.

Alves, L. M., \& Wilson, S. T. (2008). The Effects of Loneliness on Telemarketing Fraud Vulnerability Among Older Adults. Journal of Elder Abuse \& Neglect, 20(1), pp. 63-85. doi:Sem DOI

Annavarapu, S. (2016). Consuming wellness, producing difference: The case of a wellness center in India. Journal of Consumer Culture. doi:10.1177/1469540516682583

Aziz, S. J., Bolick, D. C., Kleinman, M. T., \& Shadel, D. P. (2008). The National Telemarketing Victim Call Center: Combating Telemarketing Fraud in the United States. Journal of Elder Abuse \& Neglect, 12(2), pp. 93-98. doi:10.1300/J084v12n02_10

Bardin, L. (2015). Análise de Conteúdo. São Paulo: Edições 70.

Barnhart, M., \& Peñaloza, L. (2013). Who are you calling old? Negotiating old age identity in the elderly. Journal Consumer Research, 39(6), pp. 1133-1153. doi:10.1086/668536

Baudrillard, J. (2006). O sistema dos objetos. São Paulo: Perspectiva.

Baues, C. S. (2008). Velhos consumidores, novos (super) endividados? Impacto do crédito consignado. In C. (Ed.), Envelhecimento e Subjetividade: desafios para uma cultura de compromisso social (p. 196.). Brasília: CFP. 
Bauman, Z. (2008). Vida para consumo. Rio de Janeiro: Zahar.

Bauman, Z. (2010). Vida a crédito. Rio de Janeiro: Zahar.

Bernthal, M. J., Crockett, D., \& Rose, R. L. (2005). Credit Cards as Lifestyle Facilitators. Journal of Consumer Research, 32(1), pp. 130-145. doi:10.1086/429605

Bernthal, M. J., Crockett, D., \& Rose, R. L. (2005). Credit Cards as Lifestyle Facilitators. Journal of Consumer Research, 32(1), pp. 130-145. doi:10.1086/429605

Bortoluzzi, D. A., Boligon, J. A., Hollveg, S. D., \& Medeiros, F. S. (2015). Aspectos do endividamento das famílias brasileiras no período de 2011-2014. Perspectiva, 39(146), pp. 111-124.

Britto da Motta, A. (2009). Violência contra as mulheres idosas: questão feminista ou questão de gênero. LASA (pp. 1-13). Rio de Janeiro: Associação de Estudos Latinos Americanos.

Brusky, B., \& Fortuna, J. P. (2002). Entendendo a demanda para as microfinanças no Brasil: um estudo. Rio de Janeiro: BNDES.

Burrell, G., \& Morgan, G. (1979). Sociological paradigms and organisational analysis: elements of the sociology of corporate lite. Burlington, EUA: Ashgate.

Castilhos, R. B., \& Rossi, C. A. (2009). Subindo o Morro: Consumo, Posição Social e Distinção entre Famílias de Classes Populares. In A. ROCHA, \& J. C. SILVA, Consumo na Base da Piramide (pp. 49-74). Rio de Janeiro: Mauad.

Castro, A. P., Guilam, M. C., Sousa, E. S., \& Marcondes, W. B. (2013). Violência na velhice: abordagens em periódicos nacionais indexados. Ciência \& Saúde Coletiva, 18(5), pp. 1282-1292. doi:10.1590/S141381232013000500013

Cohen, M. J. (2007). Consumer credit, household financial management, and sustainable consumption. International Journal of Consumer Studies, 31(1), p. 2007. doi:10.1111/j.1470-6431.2005.00485.x

Cooper, D. R., \& Schindler, P. S. (2016). Métodos de Pesquisa em Administração (12 ed.). São Paulo: Bookman.

Costa, A. B., \& Hennigen, I. (2010). Processos de subjetivação nas políticas de defesa do consumidor: Vulnerabilidade e cidadania em questão. Psico, 41(3), pp. 406-413.

Costa, A. B., \& Hennigen, I. (2012). Queixas dos consumidores e práticas do PROCON quanto à publicidade: por outra psicologia do consumo. Revista Interamericana de Psicología, 46(3), pp. 385-394.

Dalmoro, M., \& Vitorazzi, K. (2016). Trajetórias de Consumo: O Sujeito-Consumidor de Serviços Bancários na Terceira Idade. RAC, 20(3), pp. 328-346. doi:10.1590/1982-7849rac2016140059

FEEP. (2017, Jun. 14). Retrieved from http://www.feebpr.org.br/lucroban.htm

Fisher, M. S. (2012). Wall Street Women. Durham: Duke University Press.

Garvey, A. M., Germann, F., \& Bolton, L. E. (2015). Performance Brand Placebos: How Brands Improve Performance and Consumers Take the Credit. Journal of Consumer Research, 42(6), pp. 931-951. doi:10.1093/jcr/ucv094

Gonzalez, L. (2015). Consumo e crédito: distorções recentes e ajustes. GV-Executivo, 14(1), pp. 30-33.

Graeber, D. (2011). Consumption. Current Antropology, 52(4), pp. 489-511. doi:10.1086/660166

Graff, J., Wann, D., \& Naylor, T. H. (2002). Affluenza: the all consuming epidemic. San Francisco: BK.

Grece, A. J. (1987). Linking Dimensions of the Elderly Market to Market Planning. Journal of Consumer Marketing, 4(2), pp. 47-55. doi:10.1108/eb008196 
Hegel, G. W. (1998). Phenomenology of spirit. Oxford: Clarendon.

Hennigen, I. (2010). Superendividamento dos consumidores: uma abordagem a partir da Psicologia Social. Revista Mal-estar e Subjetividade, X(4), pp. 1173-2001.

Hennigen, I. (2012). O lado avesso do sistema consumo-crédito: (super)endividamento do consumidor. VI Encontro Nacional de Estudos do Consumo - ENEC (pp. 1-20). Rio de Janeiro: Anais ...

Hennigen, I., \& Bonazza, G. L. (2014). Publicidade do Crédito: O que se vende junto com o dinheiro? Barbarói, 40 , pp. 222-245.

Hennigen, I., \& Carvalho, A. C. (2014). Publicidade em jornais: estratégias que instigam o consumo e o lugar do crédito. Em Questão, 20(1), pp. 224-246.

Hennigen, I., \& Gehlen, G. (2012). Com a "vida" no vermelho: psicologia e superendividamento do consumidor. Pesquisas e Práticas Psicossociais, 7(2), pp. 290-298.

Hennigen, I., Schmidt, L. F., \& Souza, H. S. (2015). O crédito na publicidade televisiva: supressões, proposições e efeitos subjetivos. Arquivos Brasileiros de Psicologia, 67(3), pp. 31-46.

Ho, K. (2009). Liquidated: an ethnography of Wall Street. Durham: Duke University Press.

Irigary, T. Q., Esteves, C. S., Pacheco, J. T., Grassi-Oliveira, R., \& Argimon, I. I. (2016). Maus-tratos contra idosos em Porto Alegre, Rio Grande do Sul: um estudo documental. Estud. psicol. (Campinas), 33(3), pp. 543551. doi:10.1590/1982-02752016000300017

Kaye, A. P., \& Darling, G. (2000). Oregon's Efforts to Reduce Elder Financial Exploitation. Journal of Elder Abuse \& Neglect, 12(2), pp. 99-102. doi:10.1300/J084v12n02_11

L'Estoile, B. (2014). "Money Is Good, but a Friend Is Better": Uncertainty, Orientation to the Future, and "the Economy". Current Anthropolog, 55(9), pp. 62-73. doi:10.1086/676068

Langley, P. (2014). Consuming credit. Consumption Markets \& Culture, 17(5), pp. 417-428. doi:10.1080/10253866.2013.849594

Lazzarato, M. (2012). The Making of the Indebted Man. New York: MIT Press.

Littwin, A. (2012). Coerced Debt: The Role of Consumer Credit in Domestic Violence. California Law Review, 100(4), pp. 951-1026. doi:10.15779/Z38VR6G

Martins, T. S., Bortoluzzo, A. B., \& Lazzarini, S. G. (2014). Competição Bancária: Comparação dos Comportamentos de Bancos Públicos e Privados. Revista de Administração Contemporânea, 13(Especial), pp. 86-108. doi:10.1590/1982-7849rac20141876

Mattoso, C. L., \& Rocha, A. (2009). Significado do credito para consumidores pobres: identidade, distinção e dádiva. In A. S. Rocha, Consumo na Base da Pirâmide (pp. 75-96). Rio de Janeiro: Mauad.

Maurer, B. (2014). Postscript: is there money in credit? Consumption Markets and Culture, 17(5), pp. 512-518. doi:10.1080/10253866.2013.850037

Maurer, B., Nelms, T. C., \& Swartz, L. (2013). "When perhaps the real problem is money itself!": the practical materiality of Bitcoin. Social Semiotics, 23(2), pp. 1-17. doi:10.1080/10350330.2013.777594

Mauss, M. (2003). Ensaio Sobre a Dádiva, Forma e Razão da Troca nas Sociedades. In M. Mauss, Sociologia e Antropologia. (pp. 183-314). São Paulo: Cosac Naify.

Mendonça, P. S., Relvas, K., \& Correa, S. R. (2010). Estudo do comportamento alimentar de consumidores idosos no Brasil: alimentos preferidos, perfil do consumidor e contexto de consumo. Revista Ciências Administrativas, 16(2), pp. 529-543. 
Ministério da Saúde. (2017). Dia Mundial de Conscientização da Violência contra a Pessoa Idosa. Retrieved Mar. 27, 2017, from http://portalsaude.saude.gov.br/index.php/o-ministerio/principal/secretarias/sas/sasnoticias/24102-notificacao-compulsoria-de-violencia-contra-o-idoso-tem-evolucao-positiva

NCPEA. (2017). Financial Abuse. Retrieved Mar. 26, 2017, from National Committee for the Prevention of Elder Abuse: http://www.preventelderabuse.org/elderabuse/fin_abuse.html

Neill, L. S. (2014). The place of debt in establishing identity and self-worth in transitional life phases: young home leavers and credit. International Journal of Consumer Culture, 38(1), pp. 69-74. doi:10.1111/ijcs.12065

Nepomuceno, M., \& Laroche, M. (2012). Anti-Consumption Lifestyles and Personal Debt. Advances in Consumer Reserch, 40, pp. 699-700.

Paço. (2015). O efeito do envelhecimento na qualidade de vida e no comportamento de consumo. Revista Brasileira de Marketing, 14(1), pp. 84-96. doi:10.5585/remark.v14i1.2731

Pechmann, C., Moore, E., Andreasen, A. R., Connel, P. M., Freeman, D., Gardner, P. M., . . Soster, R. L. (2011). Navigating the Central Tensions in Research on At-Risk Consumers: Challenges and Opportunities. Journal of Public Policy \& Marketing, 30(1), pp. 23-30. doi:10.1509/jppm.30.1.23

Peñaloza, L., \& Barnhart, M. (2011). Living U.S. Capitalism: The Normalization of Credit/Debt. Journal of Consumer Research, 38(4), pp. 743-762. doi:10.1086/660116

Pereira, C. R., \& Strehlau, S. (2012). A Dádiva na Dívida: um Estudo sobre o Endividamento Familiar . V EMA (pp. 1-14). Curitiba: Anpad.

Pinto, M. R., \& Pereira, D. R. (2014). Uma teoria fundamentada das experiências de consumo de lazer por consumidores da terceira idade. Revista de Administração da Unimep, 12(3), pp. 152-183. doi:Sem DOI

Ponchio, M., \& Aranha, F. (2009). Necessidades, vontades e desejos: a influência do materialismo sobre a dívida de consumo dos paulistanos de baixa renda. In Rocha, A., \& J. F. Silva, Consumo na Base da Pirâmide: estudos brasil (1 ed., pp. 133-156). Rio de Janeiro: Mauad.

Pulina, M. (2010). Consumer behaviour in the credit card market: a banking case study. International Journal of Consumer Studies, 35(1), pp. 86-94. doi:10.1111/j.1470-6431.2010.00939.x

Reiboldt, W., \& Vogel, R. E. (2003). A Critical Analysis of Telemarketing Fraud in a Gated Senior Community. Journal of Elder Abuse \& Neglect, 13(4), pp. 21-38. doi:10.1300/J084v13n04_02

Schuster, C. E. (2014). The Social Unit of Debt: gender and creditworthiness in Paraguayan microfinance. American Ethnologist, 41(3), pp. 563-578. doi:10.1111/amet.12095

Shore, C., \& Wright, S. (2015). Audit Culture Revisited: rankings, ratings, and the reassembling of society. Current Anthropology, 56(3), pp. 421-444. doi:10.1086/681534

Soederberg, S. (2015). Debtfare States and the Poverty Industry. New York: Routledge.

Sorianno, F. C., \& Diaz, A. L. (2010). Vendo a vida passar os significados janela de velhice e de invalidez de um grupo de anciãos em um contexto de pobreza. Pesquisa em Enfermagem: Imagem e Desenvolvimento, 12(2), pp. 37-53.

Villareal, M. (2014). Regimes of Value in Mexican Household Financial Practices. Current Anthropology, 55(9), pp. 30-39. doi:10.1086/676665

Vizeu, F. (2009). Contribuições da Sociologia da Dádiva aos Estudos sobre Organizações Substantivas. 0 \& S, 16(50), pp. 409-427. doi:10.1590/S1984-92302009000300001

Warriner, G. K. (1981). Electricity Consumption by the Elderly: Policy Implications. Journal of Consumer Research, 8(3), pp. 258-264. doi:10.1086/208863 
Xiao, J. J., Sorhaindo, B., \& Garman, E. T. (2006). Financial behaviours of consumers in credit counselling. International Journal of Consumer Studies, 30(2), pp. 108-121. doi:10.1111/j.1470-6431.2005.00455.x 